\title{
Multifaceted drivers for onshore wind energy repowering and their implications for energy transition
}

Kitzing, Lena; Jensen, Morten Kofoed; Telsnig, Thomas; Lantz, Eric

Published in:

Nature Energy

Link to article, DOI:

$10.1038 / \mathrm{s} 41560-020-00717-1$

Publication date:

2020

Document Version

Peer reviewed version

Link back to DTU Orbit

Citation (APA):

Kitzing, L., Jensen, M. K., Telsnig, T., \& Lantz, E. (2020). Multifaceted drivers for onshore wind energy repowering and their implications for energy transition. Nature Energy, 5, 1012-1021.

https://doi.org/10.1038/s41560-020-00717-1

\section{General rights}

Copyright and moral rights for the publications made accessible in the public portal are retained by the authors and/or other copyright owners and it is a condition of accessing publications that users recognise and abide by the legal requirements associated with these rights.

- Users may download and print one copy of any publication from the public portal for the purpose of private study or research.

- You may not further distribute the material or use it for any profit-making activity or commercial gain

- You may freely distribute the URL identifying the publication in the public portal 


\title{
Multifaceted drivers for onshore wind energy repowering and their implications for energy transition
}

\author{
Lena Kitzing*, Morten Kofoed Jensen*, Thomas Telsnig**, Eric Lantz*** \\ * Energy Economics and Regulation Group, Department of Technology, Management and Economics, \\ DTU Technical University of Denmark, $\underline{1 k i t @, d t u . d k, ~+4524659064 ~}$ \\ ** European Commission, Joint Research Centre, Petten, The Netherlands \\ ***National Renewable Energy Laboratory, Golden, Colorado, USA
}

\begin{abstract}
Wind energy is anticipated to become a backbone of the future energy system. Aging wind turbine fleets, increasing land-use constraints and rising relevance of societal factors make the deployment of land-based (onshore) wind energy ever more complicated. Consequently, repowering is expected to become a rapidly growing point of focus for the wind industry. Here we propose a more holistic and socially informed project-level approach to analyse repowering activity that enables a more robust understanding of the process and potentials. We demonstrate that for wind pioneer Denmark, only $67 \%$ of the capacity removed in repowering projects was related to the physical space needed for a new turbine. Other factors driving repowering included regulation (e.g., noise-related, 8-17\%), development principles (e.g., aesthetics, $7-20 \%)$ and political bargaining $(4-13 \%)$. The recognition of repowering as a negotiated process between host communities and wind developers will likely be critical to unlocking the full potential of wind energy in the future.
\end{abstract}

Wind energy has emerged as a mainstream electricity production technology. While globally accounting for approximately $10 \%$ of electricity production capacity, it has taken over a leading market share in some pioneering countries 1,2 . As technology rapidly improves and operating facilities increase in age, modernisation of wind facilities becomes increasingly relevant. Although repowering, i.e., the combined activity of dismantling or refurbishing and commissioning of wind turbines, has been an active segment of the industry since the 1990s when the first commercial wind farms (commissioned in the late 1970s and early 1980s) began to require significant reinvestments and modernisation, the scale and impact of repowering on the global wind industry is expected to grow substantially in the next decade. Moreover, while repowering activity to date has been concentrated in a few markets and driven by relatively unique policy incentives, by the late 2020s, repowering could become a primary source of business activity for the wind industry across Europe, North America and China and a key to optimising wind energy utilisation in the context of energy transition. Today, only a few countries have wind energy fleets that support substantial repowering activity ${ }^{2}$. In this context, empirically derived insights from repowering activities are increasingly 
informative. Denmark is a prime case for analysis: wind energy has emerged as the primary electricity production technology, having reached a 47\% market share in 20193, and it features the oldest wind turbine fleet in the world ${ }^{1,4}$ (see also Table 1). Further factors contributing to a robust repowering market in Denmark are the size of the country, with its space limitations, and its continued desire to expand wind energy production 5 .

Table 1 Turbine fleet age structure in leading countries for onshore wind energy

\begin{tabular}{lcccccc}
\hline \hline & Denmark & Germany & Spain & EU28 & USA & China \\
\hline $\begin{array}{l}\text { Cumulative capacity installed } \\
\text { in } 2019(G W)\end{array}$ & 4.4 & 53.2 & 23.5 & 160.7 & 97.7 & 206.8 \\
\hline $\begin{array}{l}\text { Share of cumulative capacity } \\
\quad>10 \text { years }\end{array}$ & $55 \%$ & $43 \%$ & $73 \%$ & $39 \%$ & $34 \%$ & $7 \%$ \\
$\quad>15$ years & $53 \%$ & $26 \%$ & $27 \%$ & $17 \%$ & $6 \%$ & $0.4 \%$ \\
$>$ 20 years & $23 \%$ & $4 \%$ & $3 \%$ & $3 \%$ & $1 \%$ & $0.2 \%$ \\
\hline
\end{tabular}

The table shows the cumulative capacity of installed onshore wind energy and the age distribution of installed turbines in selected countries. Data from ref. 1,42,43

Repowering has historically been viewed as a means of increasing the productivity of existing projects, with improved profitability as the primary decision driver ${ }^{4,6}$. While the motivation behind much repowering activity is an improved business case for an existing facility, repowering offers an array of benefits when compared to greenfield development, including lower implementation barriers through existing grid connection, long-term empirical understanding of the available wind resource at a given site, relatively wellknown environmental impacts and accustomed neighbours. Further, subsidy schemes and short-term market incentives may encourage repowering, including incentive programs directed at repowering (see Supplementary Note 1), market premiums for new projects ${ }^{6}$, or favourable tax policy. Recent repowering in the U.S., for example, has been predominantly driven by the ability to requalify for full value and tenure of the production tax incentive program ${ }^{5}$.

From a societal perspective, repowering may offer environmental and social improvements through the replacement of older (faster-rotating and noisier) turbines with fewer and more efficient newer turbines although the new (taller) turbines may introduce new negative impacts, largely related to visibility over longer distances 7 . It is further suggested that birds and bats benefit from repowering, although challenges remain in the monitoring and assessment of bird fatalities and collision rates before and after repowering. Repowering is also particularly relevant in offering the potential to increase wind energy production from a limited area of available land, so that even when "virtually all the good wind resource sites have been taken" (using the words of a representative from the Danish wind industry) ${ }^{9}$, increases in wind energy production may still be facilitated.

Previous scientific studies on repowering can be broadly categorised into five groups: feasibility-type studies on single projects ${ }^{410-15}$; optimisation of repowering decisions, e.g., regarding time and wind farm topology ${ }^{4,16-19}$; repowering statistics, such as increased capacities or productivity, on a turbine-by-turbine comparison ${ }^{20,21}$; research on public acceptance ${ }^{6}$ and rejection factors for repowering projects ${ }^{7,22}$; and impact assessments, addressing life-cycle emissions ${ }^{23}$, visual impacts ${ }^{24}$ and impacts on birds and bats ${ }^{25-28}$. Few studies have explored techno-economic and regulatory drivers of repowering decisions $5^{5,6}$ and policy options ${ }^{16,29}$. All studies focus their scope towards the replacement of turbines on existing sites or consider a turbine-by-turbine replacement. We label this dominant approach as an 'on-site approach to repowering', and show that this is insufficient for a robust understanding of repowering decisions, processes and outcomes.

We propose a more holistic and socially informed perspective on repowering based on comprehensive project-level information. Specifically, this approach considers multifaceted drivers for repowering decisions and hence identifies dismantled turbines that are located at the same site as the new development project (on-site) as well as existing turbines in other locations that need dismantling so new turbines can be 
installed, i.e., we consider all activity that can be conditionally associated with the repowering project, regardless of spatial or temporal proximity between the existing and the new turbines, as illustrated in Fig. 1. We then identify categories for dismantling reasons in repowering projects, especially for those turbines physically located outside of the immediate project development site (off-site). Applying our approach to Denmark as an empirical case, we quantified repowering projects in their entirety. Through data collection from municipal plans ${ }^{30,31}$ project publications, geospatial analysis and semi-structured interviews with developers covering $91 \%$ of all dismantled capacity in repowering projects, we identified the full breadth of repowering projects and determined dismantling reasons. We revealed several notable differences between the traditional on-site and our more holistic and socially informed repowering perspective. Our work emphasises that a pure technology perspective alone cannot explain implementation pathways and must be supplemented with the political and social dimensions. Ultimately, this work enables more informed estimations of the future global repowering market. It also informs the challenges and opportunities presented by repowering as a means to increase renewable energy production.

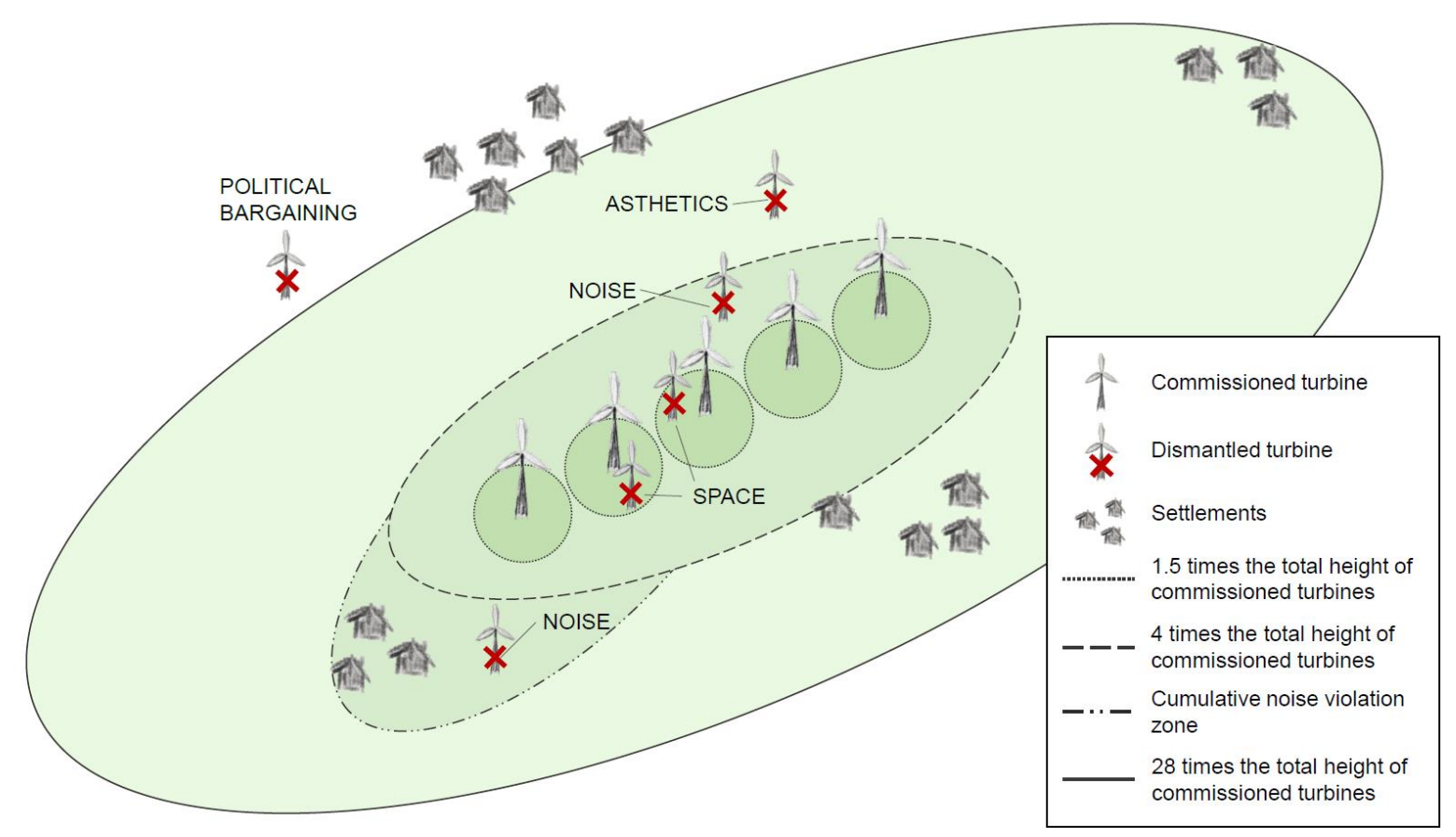

Figure 1 Illustrative map of a typical repowering project that includes on-site as well as off-site dismantling of turbines | This representative example for a (fictive) Danish repowering project is based on the median repowering project information from our dataset, in which six $600 \mathrm{~kW}$ turbines commissioned in 1997 are replaced by five new 3.3MW turbines in 2016. Annual energy production is increased by a factor of 6.5 , operations and maintenance costs declined by about $20 \%$, resulting in increased annual net cash flow of up to 0.9 million Euro assuming a high electricity price scenario. Overall Levelised Cost of Energy (LCOE) is 38-42 Euro/MWh, approximately 70-78\% of the original project LCOE. See Supplementary Note 2 for more details. Note that wind farm layout and scales are chosen to aid visualisation and not to represent a realistic case. 


\section{Repowering projects in Denmark and their market significance}

Our synthesis database contains 102 wind energy projects that have been developed in Denmark between 2012 and 2019. Table 2 provides an overview of our database by greenfield projects, repowering projects, and dismantled non-repowered turbines, which are turbines dismantled without relation to any new project. Eight projects have been excluded from the analysis (see Methods).

Table 2 Onshore wind energy projects developed in Denmark 2012-2019

\begin{tabular}{|c|c|c|c|c|c|c|c|c|c|}
\hline & $\begin{array}{c}\text { No. of } \\
\text { projects }\end{array}$ & $\begin{array}{c}\text { Total } \\
\text { no. of } \\
\text { turbines }\end{array}$ & $\begin{array}{c}\text { Average } \\
\text { no. of } \\
\text { turbines } \\
\text { per project }\end{array}$ & $\begin{array}{l}\text { Range of } \\
\text { no. of } \\
\text { turbines } \\
\text { per project }\end{array}$ & $\begin{array}{c}\text { Total } \\
\text { capacity } \\
{[\mathrm{MW}]}\end{array}$ & $\begin{array}{c}\text { Average } \\
\text { capacity } \\
\text { per project } \\
{[\mathrm{MW}]}\end{array}$ & $\begin{array}{c}\text { Average } \\
\text { capacity per } \\
\text { turbine } \\
{[\mathrm{MW}]}\end{array}$ & $\begin{array}{c}\text { Range of } \\
\text { capacity } \\
\text { per project } \\
{[\mathrm{MW}]}\end{array}$ & $\begin{array}{c}\text { Average } \\
\text { turbine age at } \\
\text { dismantling }\end{array}$ \\
\hline $\begin{array}{l}\text { Greenfield } \\
\text { projects }\end{array}$ & 58 & 272 & 4.7 & $1-21$ & 804.3 & 13.9 & 3.0 & $2-46.8$ & \\
\hline $\begin{array}{l}\text { Repowering } \\
\text { projects (net) }\end{array}$ & 36 & -1 & 0 & $-14-16$ & 576.8 & 16.04 & & $0.15-65.9$ & \\
\hline $\begin{array}{l}\text { Repowering } \\
\text { projects (gross } \\
\text { additions) }\end{array}$ & & 220 & 6.1 & $1-22$ & 731.9 & 20.3 & 3.3 & $0.2-77.4$ & \\
\hline $\begin{array}{l}\text { Repowering } \\
\text { projects (gross } \\
\text { reductions) }\end{array}$ & & 221 & 6.1 & $1-35$ & 155.1 & 4.3 & 0.7 & $0.075-23.0$ & 18.6 \\
\hline $\begin{array}{l}\text { Non- } \\
\text { repowered } \\
\text { dismantled } \\
\text { turbines }\end{array}$ & & 380 & & & 78.8 & & 0.2 & & 24.4 \\
\hline
\end{tabular}

See Methods for details on the derived numbers, and Supplementary Note 3 for more detailed results.

More than a third (38\%) of all new wind energy developments have been repowering projects. Only 10\% more capacity was developed in greenfield projects than in repowering. In repowering projects, net capacity additions amounted to $576.8 \mathrm{MW}$, while, at the same time, the net number of turbines decreased by 1 . Overall, we observe $1.3 \mathrm{GW}$ of net capacity additions and a net reduction of 109 turbines, considerably reducing the number of turbines physically present in the landscape. This shows that newer, more-efficient turbines have replaced earlier, less-efficient turbines over time.

Turbines removed in repowering projects are on average 5.8 years younger than those dismantled on a stand-alone basis (non-repowering). Interviewees confirmed that most of the dismantled turbines in repowering projects had not reached the end of their operational lifetime but were dismantled prematurely so that the new project could be executed. This emphasises the importance of distinguishing between endof-life decisions and repowering decisions, which involve multiple social and economic considerations.

Further, dismantled repowering turbines are on average 3.4 times as large as dismantled non-repowered turbines. Although repowering comprises $66 \%$ of the total dismantled capacity, it only comprises $37 \%$ of the total number of dismantled turbines. Because of the size difference between dismantling in repowering and as a separate activity, we further analyse both capacity and number of turbines.

Repowering has played an increasingly significant role in Denmark since 2012, both in terms of capacity (Table 3) and the number of turbines (Table 4). Repowering shares have been steadily increasing for gross added capacity and number of installed turbines. The relatively low starting values in 2012 of $23 \%$ may be due to the removal of a pre-existing repowering incentive scheme that was in place from 2005 to $2011^{32}$, leaving a weak market for repowering at the beginning of the observed period. In the last observed year, 
the repowering market share jumped to an unprecedented level of $86 \%$ of gross added capacity, or $87 \%$ of added wind turbines.

Repowering shares in the dismantling of turbines were even more significant, though varying over time. Repowering has been the principal reason for capacity dismantling in 5 of the eight years investigated, while the repowering share in capacity reductions ranged between 17\% in 2015 and $92 \%$ in 2013. Variations in repowering shares for the number of dismantled turbines follow a different pattern, as turbine sizes have been increasing in recent years.

Table 3 Annual wind turbine capacity additions and reductions in megawatts

\begin{tabular}{|c|c|c|c|c|c|c|c|c|c|}
\hline & 2012 & 2013 & 2014 & 2015 & 2016 & 2017 & 2018 & 2019 & Total \\
\hline Repowering - gross additions & 30.0 & 122.4 & 40.5 & 92.9 & 104.8 & 126.9 & 108.3 & 106.2 & 732 \\
\hline Repowering - gross reductions & -0.8 & -21.7 & -30.8 & -2.7 & -21.4 & -47.1 & -8.5 & -22.3 & -155 \\
\hline Greenfield & 103.2 & 167.3 & 57.5 & 110.9 & 94.3 & 174.9 & 79.5 & 16.8 & 804 \\
\hline Separately dismantled turbines & -1.0 & -1.8 & -6.2 & -13.5 & -30.0 & -18.8 & -3.0 & -4.4 & -79 \\
\hline Annual net capacity instalment & 131 & 266 & 61 & 188 & 148 & 236 & 176 & 96 & 1302 \\
\hline Share of repowering: commissioned & $23 \%$ & $42 \%$ & $41 \%$ & $46 \%$ & $53 \%$ & $42 \%$ & $58 \%$ & $86 \%$ & $48 \%$ \\
\hline Share of repowering: dismantled & $43 \%$ & $92 \%$ & $83 \%$ & $17 \%$ & $42 \%$ & $71 \%$ & $74 \%$ & $84 \%$ & $66 \%$ \\
\hline
\end{tabular}

Note: The data exclude test and small-scale (household) turbines $(<25 \mathrm{~kW})$, see Methods

Table 4 Annual number of wind turbine additions and reductions

\begin{tabular}{|c|c|c|c|c|c|c|c|c|c|}
\hline & 2012 & 2013 & 2014 & 2015 & 2016 & 2017 & 2018 & 2019 & Total \\
\hline Repowering - gross additions & 10 & 38 & 13 & 31 & 32 & 37 & 33 & 26 & 220 \\
\hline Repowering - gross reductions & -1 & -26 & -53 & -6 & -32 & -67 & -8 & -28 & -221 \\
\hline Greenfield & 34 & 63 & 21 & 38 & 37 & 51 & 24 & 4 & 272 \\
\hline Separately dismantled turbines & -3 & -9 & -37 & -70 & -145 & -94 & -11 & -11 & -380 \\
\hline Annual net turbine instalment & 40 & 66 & -56 & -7 & -108 & -73 & 38 & -9 & -109 \\
\hline Share of repowering: commissioned & $23 \%$ & $38 \%$ & $38 \%$ & $45 \%$ & $46 \%$ & $42 \%$ & $58 \%$ & $87 \%$ & $45 \%$ \\
\hline Share of repowering: dismantled & $25 \%$ & $74 \%$ & $59 \%$ & $8 \%$ & $18 \%$ & $42 \%$ & $42 \%$ & $72 \%$ & $37 \%$ \\
\hline
\end{tabular}

Note: The data exclude test and small-scale (household) turbines $(<25 \mathrm{~kW})$, see Methods

More detailed results from our dataset, including on market shares of project developers and turbine manufacturers, can be found in Supplementary Note 3.

\section{Categorising dismantled turbines into repowering reasons}

As argued earlier, more holistic and socially informed repowering analysis must include all dismantled turbines related to a repowering project regardless of distance and time. For a deeper understanding of the reasons behind dismantling turbines in repowering projects, we conducted in-depth interviews with leading wind developers in Denmark, covering $91 \%$ of all capacity dismantled in repowering projects in the investigated time frame. From the interviewee responses, eight mutually exclusive categories emerged for dismantling existing turbines in repowering projects, as summarised in Table 5. 

interviews

Space: Physical requirement for the installation of new turbines, such as a space requirement for new foundations, access roads, setbacks and grid infrastructure. Aside from the stated reasons by the interviewees, we included dismantled turbines within the radius of 1.5 times the total height of the new wind turbine also to be in this category, as a minimum distance required to prevent the hazard from a collapse of turbine towers.

Noise: Violation of the cumulative noise emissions within a radius of 28 times the total height of the planned wind farms. A noise emission difference less than $15 \mathrm{~dB}$ between existing wind turbines and planned wind turbines at an inhabited property induces a cumulative noise calculation. If this calculation exceeds the noise limit, either noise reduction on the new turbines or dismantling of the existing turbines are conceivable options.

Aesthetics: A disturbance of the scenic or aesthetic values in the landscape. The Environmental Impact Assessment requires a visual impact analysis concerning disturbances of aesthetic values within a radius of 28 times the total height of the planned wind turbines. Focusing on location, design and the interaction between existing turbines and planned wind turbines, the visual impact analysis can require the dismantling of turbines.

Aesthetics or noise: Either a violation of noise emissions or a disturbance of the scenic or aesthetic values in the landscape caused the developer to dismantle existing wind turbines. Although the interviewee could not single out one reason for the dismantling, they have explicitly negated politics as a reason for turbines in this category.

Politics: During local development and planning dialogues, informal requests by local politicians, proactive suggestions by developers or voluntary agreements by both parties are put forward to satisfy the agreement on the development of the new project. All of these actions involve the dismantling of existing wind turbines located in the municipality based on subjective intentions as a condition for the new project.

Politics or aesthetics: The interviewees could not point out precisely if the main driver was politics or aesthetics. Some mentioned that local politicians tend to use the disturbance of aesthetic values in the landscape to argue for the removal of existing wind turbines, which made selecting between aesthetics or politics difficult.

Politics, aesthetics or noise: For some turbines, a differentiation between the dismantling reasons is unobtainable. A combination of factors may prompt the developer to plan the dismantling of existing wind turbines before the permit proposal. In the pre-permit process, the developer identifies problematic wind turbines knowing that they will be chosen for dismantling as a result of politics, noise or aesthetics, thereby saving time on wind farm design, noise calculations and the visual impact assessment.

Unclassified: Unassigned reasons for dismantling wind turbines. This category contains those wind turbines for which our interviews or the local development plans do not cover the motivations behind the dismantling.

Note: See the Methods section for a more comprehensive description of reasons

It is noteworthy that none of the interviewees named profitability or other economic reasons as drivers for dismantling turbines in repowering projects. On the contrary, talking about the market for repowering, one interviewee stated that greenfield projects generally provide the highest profits. Repowering is seen as a costly necessity, not least because the existing turbines often have to be purchased at a high cost before they can be dismantled. This is notwithstanding the fact that some older wind turbines may not have been feasible to operate much longer, and in general may not have fulfilled the owner's expectations, e.g. in regard to production volumes, failure rate and downtime.

While we focused our study on repowering from the developers' perspective, others who have investigated the attitudes of local politicians towards wind energy projects and repowering, e.g. in the Czech Republic, found that they equally consider economic value creation and displeasure of local residents and other local stakeholders ${ }^{22}$. Concrete reasons that are likely to contribute to dismantling requests in our context were found to involve opposition of local residents, local landscape disruption and impact on well-being (noise) ${ }^{22}$. 
Table 6 Wind turbines dismantled in repowering projects by dismantling reason

\begin{tabular}{|c|c|c|c|c|c|c|c|c|}
\hline & Space & Noise & Aesthetics & $\begin{array}{l}\text { Aesthetics } \\
\text { or Noise }\end{array}$ & Politics & $\begin{array}{l}\text { Politics or } \\
\text { Aesthetics }\end{array}$ & $\begin{array}{l}\text { Politics, } \\
\text { Aesthetics } \\
\text { or Noise } \\
\end{array}$ & Unclassified \\
\hline $\begin{array}{l}\text { Number } \\
\text { turbines }\end{array}$ & 139 & 28 & 20 & 10 & 6 & 6 & 10 & 2 \\
\hline Capacity [MW] & 103.8 & 12.2 & 11.3 & 6.7 & 6.3 & 5.9 & 7.4 & 1.5 \\
\hline $\begin{array}{l}\text { Average capacity } \\
\text { per turbine }[\mathrm{MW}]\end{array}$ & 0.747 & 0.435 & 0.566 & 0.669 & 1.050 & 0.983 & 0.740 & 0.750 \\
\hline Share of number & $63 \%$ & $13 \%$ & $9 \%$ & $5 \%$ & $3 \%$ & $3 \%$ & $5 \%$ & $0.9 \%$ \\
\hline Share of capacity & $67 \%$ & $8 \%$ & $7 \%$ & $4 \%$ & $4 \%$ & $4 \%$ & $5 \%$ & $1.0 \%$ \\
\hline
\end{tabular}

Table 6 shows the results of our categorisation effort. We found that space is the strongest motivation for dismantling turbines in repowering projects in Denmark, with $67 \%$ of the total capacity and $63 \%$ of the total number of turbines, respectively. Space is, of course, a well-known reason given that most repowering projects are developed from existing wind farm sites. This category generally corresponds to what is typically captured by analyses using an on-site approach.

The second major individual reason for dismantling turbines in repowering is a violation of the cumulative noise emissions, comprising $13 \%$ of the total number of turbines and $8 \%$ of the full capacity dismantled. Hence, noise regulation in Denmark has a significant impact on repowering projects. This impact was also underlined by several of the interviewees. Here, it is relevant to note that noise regulation differs significantly from country to country. Interestingly, turbines removed because of noise have the smallest average capacity size $(435 \mathrm{~kW})$ and highest average age (22.1 years, see Fig. 2, panel b).

It was sometimes impossible for developers to point to a specific reason for dismantling a particular turbine, especially where aesthetics and politics were involved. We thus analyse the remaining categories jointly. The individual category aesthetics comprises $9 \%$ of the total number of turbines and $7 \%$ of the total capacity dismantled. However, aesthetics also play a role in three mixed categories (aesthetics or noise; politics or aesthetics; politics, aesthetics or noise). Assuming that all turbines in these three categories were removed because of aesthetics, it would become the second most significant reason, comprising $21 \%$ of the total number of turbines and $20 \%$ of the total capacity dismantled. The individual category politics comprises $3 \%$ of the total number of turbines and $4 \%$ of the total capacity dismantled. If all turbines in the respective mixed categories (politics or aesthetics; politics, aesthetics or noise) were dismantled because of politics, the category politics would contain $10 \%$ of the total number of dismantled turbines or $13 \%$ of the removed capacity.

\section{Considerable differences in distance, age, repowering factor}

The distance between dismantled and newly installed turbines differs considerably across the categories (see Fig. 2, panel a), with the category 'politics' having the highest spread. With a dismantled turbine located 4.6 $\mathrm{km}$ (31 times the total height) away from the nearest new turbine, it is apparent that politics can target a broad range of existing turbines. As stated by one interviewee, politics seem spatially unrestricted within the municipality because voluntary agreements between developers and politicians can include the removal of any existing turbines within the municipal area. Some interviewees perceived that some municipalities had an informal one-for-one requirement, and one interviewee confirmed that this was the very reason why they chose to dismantle a specific older existing turbine located in the municipality from their portfolio. Concerning the one-for-one requirement, another interviewee elaborated on a current project (to be commissioned in 2022), in which, as part of a voluntary agreement, they would dismantle several turbines located more than $10 \mathrm{~km}$ away from the site of the new project. 


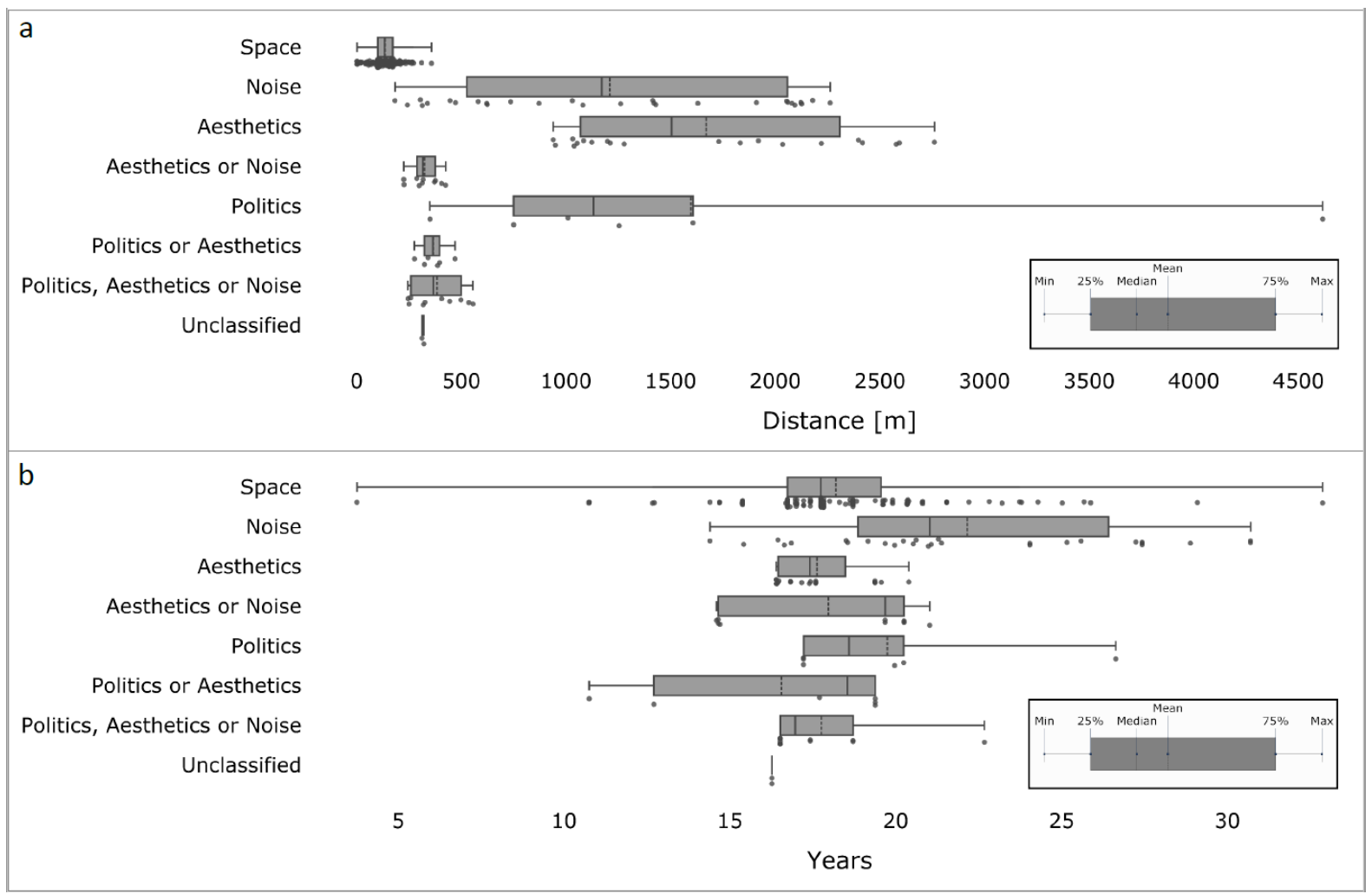

Figure 2 Distribution of wind turbines in repowering projects by dismantling category $\mid$ Panel a depicts the nearest distance between dismantled and installed wind turbines; Panel b depicts the age of dismantled turbines.

In contrast to the informal nature of politics-related agreements, formal regulations are in place that restrict the farthest impact distances of noise and aesthetics: the relationship between existing and planned turbines only needs to be evaluated within a radius of 28 times the total height of the planned turbines ${ }^{33}$. Here, the observed maximum removal distances are $2.3 \mathrm{~km}$ (15 times the total height) for noise and $2.8 \mathrm{~km}(18.5$ times the total height) for aesthetics.

Turbine age at dismantling varies considerably across the categories (see Fig. 2, panel b). The space category shows some of the highest and lowest dismantling ages, ranging from 3.8 years to 32.9 years with a median value of 17.4 years. The average age for the noise category is 22.1 years, the highest of all groups, suggesting that older turbines more commonly induce a violation of noise emission limits. Those older turbines are mechanically louder and have less sound insulation than newer turbines, as stated by one of the interviewees.

In seven of the eight categories, both the median and average value for the operating turbine lifetime are below 20 years. This is surprising because turbines installed in Denmark between 1996 and 2008 are guaranteed government support for 20 years $^{34}$. Hence, many of these turbines forego support payments because of dismantling. This reinforces the idea that repowering is seldom a technical end-of-lifetime decision or even an end-of-support decision. One interviewee stated that they continuously monitor their fleet of existing turbines and evaluate the turbines' economic viability regarding including them in a new repowering project; hence, the current age of the existing turbine is, in itself, largely irrelevant, and merely a parameter in the broader economic evaluation.

Our analysis revealed that turbines in repowering projects are dismantled on average 5.8 years earlier than those separately dismantled (non-repowering) (see Table 2). These 'lost' years of production constitute foregone value creation. Of course, the lost production is offset by the additional value created from the 
larger and more efficient new turbines. However, it can be argued that for the turbines that fall within the more intangible dismantling categories, including aesthetics and politics, the value of lost production should be considered and weighed against the societal willingness to pay for the turbine removal. Approximating the value of lost production through electricity market prices, we estimate between 0.27 and 0.43 million Euro per turbine is lost as a result of premature dismantling, with the lower value reflecting the average of all categories and the higher one the three categories that capture non-physical reasons for dismantling (i.e., aesthetics; politics; aesthetics and politics). This value compares with estimated operations and maintenance cost of 0.25 to 0.29 million Euro per turbine over a 5.8-year period ${ }^{35}$. The general comparability of these ranges points toward economic as well as societal factors as drivers of turbine dismantling in repowering projects.

The presented empirical data demonstrate the difficulties in analysing repowering strictly from an on-site perspective. Likewise, simply broadening the scope to a larger radius around the new development site comes with significant limitations, as illustrated in Table 7, which depicts the total number of dismantled turbines and capacity as a function of proximity to the nearest new turbine within each repowering project, along with the share of dismantled turbines captured by the respective approach.

Table 7 Dismantled wind turbines in repowering projects as a function of proximity to the nearest commissioned new turbine by capacity and number of turbines

\begin{tabular}{|c|c|c|c|c|c|c|c|c|}
\hline & \multicolumn{6}{|c|}{ Proximity to the nearest commissioned repowering turbine } & \multirow[b]{2}{*}{$\begin{array}{l}\text { Cate- } \\
\text { gory } \\
\text { Space }\end{array}$} & \multirow[b]{2}{*}{$\begin{array}{c}\text { All } \\
\text { Dismantled } \\
\text { Turbines }\end{array}$} \\
\hline & $\begin{array}{l}<1 \times \\
\text { Total } \\
\text { Height of } \\
\text { a New } \\
\text { Turbine }\end{array}$ & $\begin{array}{l}<2 \times \\
\text { Total } \\
\text { Height of } \\
\text { a New } \\
\text { Turbine }\end{array}$ & $\begin{array}{l}<3 \times \\
\text { Total } \\
\text { Height of } \\
\text { a New } \\
\text { Turbine }\end{array}$ & $\begin{array}{l}<4 \times \\
\text { Total } \\
\text { Height of } \\
\text { a New } \\
\text { Turbine }\end{array}$ & $\begin{array}{l}<5 \times \\
\text { Total } \\
\text { Height of } \\
\text { a New } \\
\text { Turbine }\end{array}$ & $\begin{array}{l}<10 \times \\
\text { Total } \\
\text { Height of } \\
\text { a New } \\
\text { Turbine }\end{array}$ & & \\
\hline $\begin{array}{l}\text { No. of dismantled } \\
\text { turbines identified }\end{array}$ & 75 & 147 & 168 & 174 & 179 & 199 & 139 & 221 \\
\hline $\begin{array}{l}\text { Share of dismantled } \\
\text { turbines captured }\end{array}$ & $33.9 \%$ & $66.5 \%$ & $76.0 \%$ & $78.3 \%$ & $81.0 \%$ & $90.0 \%$ & $63 \%$ & $100 \%$ \\
\hline $\begin{array}{l}\text { Dismantled capacity } \\
\text { identified [MW] }\end{array}$ & 55.9 & 110.1 & 125.6 & 129.9 & 134.1 & 144.5 & 103.8 & 155.1 \\
\hline $\begin{array}{l}\text { Share of dismantled } \\
\text { capacity captured }\end{array}$ & $36.0 \%$ & $71.0 \%$ & $80.9 \%$ & $83.8 \%$ & $86.4 \%$ & $93.2 \%$ & $67 \%$ & $100 \%$ \\
\hline $\begin{array}{l}\text { Net no. of turbine } \\
\text { repowering factor }\end{array}$ & 2.93 & 1.50 & 1.31 & 1.26 & 1.23 & 1.11 & 1.58 & 1 \\
\hline $\begin{array}{l}\text { Net capacity } \\
\text { repowering factor }\end{array}$ & 13.10 & 6.65 & 5.83 & 5.63 & 5.46 & 5.06 & 7.05 & 4.72 \\
\hline
\end{tabular}

Note: The two last rows denote the net repowering factor, i.e., the ratio between commissioned and dismantled turbine capacity in repowering projects

We observe that increasing the radius of investigation around the newly developed turbine also increases the likelihood of capturing a higher share of relevant dismantled turbines. However, even a radius equal to 10 times the total height of a new turbine fails to capture $10 \%$ of the associated dismantled turbines. Furthermore, such a simplistic radius approach bears the risk of including unrelated dismantling of turbines in the repowering statistics. Therefore, it is still necessary to manually establish a causal relationship between a commissioned and dismantled turbine within each repowering project.

The on-site approach would equally fall short of estimating a realistic net repowering factor, which is the ratio between commissioned and dismantled values (number of turbines or capacity), and hence denotes the amount commissioned for every unit dismantled. Considering all causally identified dismantled turbines in repowering projects, we obtain a net capacity repowering factor of 4.72, in contrast to 13.10 if using a radius derived from one time the total height of the new turbines. If we only consider those turbines that 
have been identified in the space category, the net repowering factor would equal 7.05. Hence, project-level information and causal relationship building are crucial in determining the full extent of repowering impacts.

\section{Discussion $\&$ conclusions}

This work proposes a more holistic and socially informed project-based perspective on wind plant repowering that starts from the development of new projects and explores the need for and drivers of removing existing turbines to enable the realisation of new wind energy facilities. Our results suggest that focusing on end-of-life considerations and assuming simple on-site localised replacement of existing turbines is insufficient to truly understand repowering impacts and opportunities. We demonstrate this in a case application for Denmark, where more than a third of all wind energy development projects between 2012 and 2019 involved repowering. Only 67\% of the capacity removed in repowering projects was related to turbines that occupied the physical space needed for a new turbine. We identified several other reasons for dismantling, including regulation (e.g., noise-related, 8-17\% of removed capacity) and development principles (e.g., aesthetics, 7-20\% of removed capacity). Also, political bargaining around the dismantling of unwanted older turbines was not uncommon (4-13\% of removed capacity).

The broader perspective offered by our approach highlights how the repowering process is not a matter of turbine replacement but a negotiation between the developer and the local host community about how wind energy should coexist with the community given the changes that the introduction of the new technology might induce. There is no doubt that repowering can increase the total contribution of wind energy from a given land area. However, we demonstrate that this contribution is not as high as theoretically possible based on physical considerations alone. Considering only on-site replacement of turbines might lead to the misperception that a net repowering factor of 7.05 could have been achieved in Denmark, i.e., that the installed capacity after completing an average repowering project would be 7.05 times higher than the original capacity. In fact, by establishing causal relationships between repowering projects and all dismantled turbines, including the additional off-site capacity removed, we observed that the actual net capacity repowering factor per project was only 4.72 . While repowering potential within a project may still be significant, it is weakened by the conditional dismantling of unwanted off-site turbines and the associated land-use and societal considerations that this dismantling may serve. In addition, turbines dismantled in repowering projects achieved an average operating age of 5.8 years less than those dismantled on a standalone basis (non-repowering) and are often dismantled before reaching the end of their operational life. Accordingly, repowering may arrive earlier and with a stronger force than would be predicted when taking an end-of-life perspective.

Notwithstanding the relatively lower net repowering factor and shorter lifetime of dismantled repowered turbines, our analysis also indicates that repowering, in combination with technological innovation, can help reduce the impacts of wind turbines on neighbouring communities. In a sense, repowering provides dual benefits to society-increased clean energy supply and fewer turbines present in the landscape. Although these benefits do not come without trade-off (such as higher visibility over longer distances), they are significant in regions where space is limited, and increased deployment of wind energy is desired. This situation may be increasingly experienced with a growing reliance on renewable power to serve clean energy needs.

As Denmark is a global pioneer of wind energy and repowering, the experiences observed here are anticipated to become increasingly relevant for other countries and regions. Of course, we acknowledge that many of the non-space-related reasons for dismantling turbines are idiosyncratic and depend on the physical, political and social landscape in a country. Nevertheless, the diversity of repowering and dismantling drivers captured here illuminates the complex and multifaceted decision process that constitutes repowering and illustrates significant implications for policymakers and planners trying to understand the potential of wind power to serve their energy needs. 


\section{Methods}

\section{Approach}

We take a new wind energy development project as the starting point of the analysis. From this lens, we consider all turbines that are necessary to be dismantled to enable the undertaking of the new project (as a conditional requirement). We use the term dismantling, but in principle, our approach can capture both the complete dismantling of turbines (also referred to as full repowering ${ }^{4}$ ), and the installation of new equipment (e.g., drivetrain and rotor) on an existing tower and/or foundation (also referred to as partial repowering ${ }^{4}$ ). We emphasise that the analysis must include the dismantling of existing turbines not only at the location of the new project undertaking (on-site), but also those located elsewhere (off-site). Furthermore, existing turbines may be dismantled years before the new turbines are installed. Therefore, repowering must reflect a combined action of dismantling existing turbines and establishing new turbines, regardless of spatial or temporal proximity. We are, thus, investigating the conditional relationship between capacity reduction and capacity addition. This enables us to reveal notable differences between repowering projects (comprising both commissioning new turbines and dismantling existing turbines) and greenfield projects (only comprising commissioning of new turbines) for several key indicators, such as project size and lifetime.

Applying our approach on an empirical case we created a synthesised database of all approved Danish wind projects between 2012 and 2019. We constructed the database by using publicly available sources and semistructured interviews with leading wind developers in Denmark. Our database has two key advantages. First, it is exhaustive on a project-level basis, whereas previous databases focus solely on technical specifications or the physical planning of wind turbines. Second, our database allows for a comprehensive overview of the extent of repowering projects in Denmark, whereas most previous studies only provide a general overview (in the form of 'bulk' sizes or turbine-per-turbine comparisons). Our database is uniquely suited to identify the reasons for dismantling turbines in repowering projects. We created our database between May 2018 and September 2019 in three major stages. In the first stage, we manually extracted data and coded the database. In the second stage, we interviewed leading wind developers to collect qualitative data on the motivations behind dismantling turbines in repowering projects. In the third stage, we synthesised and analysed the rich data from the interviews into our database.

\section{Data selection}

We limited our time horizon to the period between 2012 and 2019. We excluded the years before 2001 because of discontinued regulations that may have distorted repowering decisions from today's perspective. We also excluded the years from 2001 to 2011. During that period, the Danish government provided policy incentive programs for repowering (see Supplementary Note 1) that could have confounded our analysis. Third, we excluded projects involving research and test turbines, as these turbines are subject to different regulations. Out of the 102 identified wind projects, eight projects were experimental test projects, i.e., turbines established and dismantled at test sites. In total, 70 test turbines were dismantled during the investigated period. Fourth, we excluded household wind turbines, i.e., turbines with a generation capacity of $25 \mathrm{~kW}$ or less, as there are different regulations for these types of turbines. During the investigated period, 77 household turbines were dismantled. Fifth, we excluded a dismantling project that was part of an infrastructure development project, where 26 turbines were dismantled because of the construction of the Femern tunnel in Southern Denmark. Overall, we determined that 221 out of the relevant 601 dismantled turbines were repowering related.

Note that we included all wind energy projects that have been developed, approved and where project execution has started until the end of 2019. We have included two repowering projects, with a total of 106.2 MW, for which the commission date was rescheduled from 2019 to primo 2020. Decommissioning of turbines for one project commenced in November 2019, while for the other, it was postponed into 2020. 


\section{Data sources}

We constructed the database by using three primary sources. The first source is the master data registry of wind turbines from the Danish Energy Agency ${ }^{31}$. The master data registry is a comprehensive data set consisting of post-construction information. The data set contains information, such as identification number, technical specifications of the turbine and Universal Transverse Mercator (UTM) coordinates, on all commissioned and dismantled turbines in Denmark. The Danish Energy Agency periodically updates the data set under European Union directive 2001/77/EC 36 . The second source is local development plans regarding wind projects, which we retracted online from the Danish Business Authority ${ }^{30}$. Local development plans set out the framework for future planned projects and describe the project comprising information on the location, appearance, number of commissioned and in most cases also dismantled turbines and an Environmental Impact Assessment (EIA). The third source is interviews with repowering wind developers in Denmark.

\section{Data collection: desktop research}

We manually reviewed all approved and undertaken local development plans regarding wind turbines from 2012 to 2019. For each local development plan, we proceeded as follows.

Using spatial analysis in the proximity of the local development plan, we identified and connected commissioned and dismantled turbines from the master data registry to the respective local development plan in our database. To identify the commissioned turbines, the local development plan specifies exact locations on maps. By translating these locations into UTM coordinates in Google Earth, we were able to locate the matching commissioned turbines in the master data registry of wind turbines. The local development plan often does not provide exact locations for the dismantled turbines. Instead, the local development plan describes the location of the existing turbines within the text. Consequently, using the Euclidean distance formula with the UTM coordinates, we calculated each distance between all dismantled turbines and the centre point of the local development plan. Next, we sorted the distances according to the shortest value. Using the sorted list of dismantled wind turbines, we used Google Earth to find existing turbines that best matched the location of those mentioned in the local development plan. This evaluation served two purposes, to identify the turbines mentioned in the local development plan, and to check if there were any unmentioned dismantled wind turbines in the nearby area that had a possible connection to the local development plan.

After the spatial analysis, we categorised the project from the local development plan as either a greenfield, repowering or demonstration project. Then, we searched through the local development plan and the EIA to identify the reason for dismantling each turbine in repowering projects. If the local development plan or the EIA mentioned a specific reason, we included that information in our database, mostly for later verification in the interviews. Finally, we searched through the local development plan to obtain any contact details regarding the developer of the project. To account for missing details on the developer, we also drew on web searches of property valuation settlements, news articles and company announcements.

To ensure that we identified all approved wind farm projects from 2012 to 2019, we consistently checked if we had assigned all commissioned wind turbines from the master data registry of wind turbines to a local development plan in our database. In the case of any unassigned commissioned wind turbines, we used the associated UTM coordinates together with an interactive map provided by the Danish Business Authority 32 to detect if any local development plan existed in the area. As a result, we identified all wind projects in Denmark from 2012 to 2019.

\section{Data collection: interviews}

We conducted five in-depth semi-structured interviews with the leading wind developers in Denmark, comprising 52.8\% of all repowering projects between 2012 and 2019 and $72.4 \%$ of all dismantled turbines. 
Additionally, we conducted eight informal interviews with local wind developers, comprising $22.2 \%$ of all approved repowering projects in the same period, or $16.3 \%$ of all dismantled turbines. Overall, our interviews cover $89 \%$ of all dismantled turbines in repowering projects in the designated time frame, and $91 \%$ of all dismantled capacity in repowering projects. For each project covered, we received responses on all turbines in the respective project. Using our interviews and the special planning reports, we have identified a specific reason for $94 \%$ for all turbines dismantled in repowering projects.

We conducted the interviews by phone between March 2019 and September 2019. The in-depth interviews lasted 45-70 minutes. We recorded and transcribed the interviews. The informal interviews lasted 10-25 minutes. Here, we took hand-written notes. All interviews were conducted in Danish. In both interview types, we informed the interviewees that we would reveal neither their identity nor their affiliation, according to the Chatham House Rule ${ }^{37}$.

Using a protocol, we structured the in-depth interviews into two main parts. In the first part, we asked the interviewees five open questions:

1. How would you define a repowering project?

2. Can you delineate the motivations behind the dismantling of wind turbines during a repowering project?

3. What would be a required minimum space between planned and existing wind turbines?

4. Does your company have any guidelines in selecting existing wind turbines for dismantling?

5. What happened with the dismantled wind turbines?

In the second part of the protocol, we asked project-specific questions to establish the motivations behind dismantling each turbine in the respective repowering projects. In the informal interviews, we only focused on the second part of the protocol.

After the interviews, we analysed the transcripts and notes to identify and classify the reasons for dismantling wind turbines in repowering projects. Based on this, we found eight mutually exclusive categories for dismantling turbines in repowering projects, as follows.

(1) Space. Commonly, developers construct repowering projects at existing project sites. Therefore, it is often necessary to dismantle existing wind turbines on that site, because of physical constraints. Developers reported that these physical constraints cover the land use needed for the installation and operation of the individual new planned wind turbine, such as a space requirement for access roads, setbacks, foundation and grid infrastructure.

Aside from the statements given by the interviewees and for consistency reasons, we categorised all existing wind turbines dismantled within the proximity of 1.5 times the total height of the new wind turbine in this category. We see the value of 1.5 as a minimum distance required to prevent a collapse of the turbine tower, a crash of a wind turbine, or a detached blade from the hub. Note that this is our consolidated estimate of a minimum distance. When asked about a required minimum distance between planned and existing wind turbines, the interviewees gave no fully conclusive answer. In an additional legal analysis (reviewing primary sources of law), we found no state-level legislation or statutes concerning a minimum distance between wind turbines. Additionally, we examined legal statutes in all municipalities involved with repowering projects. We only found guidelines specifying a distance corresponding to 3-5 times the rotor diameter between turbines when planning new wind farms ${ }^{38}$. These guidelines do not consider the relationship between existing and planned wind turbines where the hub height differs, and wake effects might be insignificant. Another guideline states a minimum distance of 1 time the total height of the wind turbine to main roads and railroads, in case of crash down or falling ice debris ${ }^{38}$.

(2) Noise. Wind turbines generate noise as a result of moving mechanical parts and the aerodynamic effects of air passing over the blades. According to Danish noise regulation, a developer must calculate the cumulative noise emissions from the planned and existing wind turbines at a property if the difference in noise emission from the planned and the existing wind turbines is less than $15 \mathrm{~dB}^{39}$. The cumulative noise 
emissions include outdoor open space areas near the property and low-frequency noise indoors. If the cumulative noise emissions violate the noise limits, the developer can either choose to reduce the noise from the planned wind turbines, thereby reducing the generation output, or dismantle existing wind turbines.

(3) Aesthetics. Aesthetics are defined as the visible impact on the landscape of individual wind turbines. Because of growing height and rotor diameter, wind turbines are more visible over greater distances within the local community. Some citizens feel affected by the presence of wind turbines with regard to a 'disfigurement' of the landscape. This feeling is subjective; while some see wind turbines as a positive element in the transition to sustainability, others may see them as a disturbance to scenic or aesthetic values.

Using a visual impact analysis, the EIA includes an evaluation of the disturbances of aesthetic values within 28 times the total height of the planned wind turbines. The evaluation focuses on location, design and the interaction between the proposed new wind turbines and the existing infrastructure. Several developers mentioned in our interviews that the difference in height and rotational speed between planned and existing wind turbines are two of the main aesthetic factors that cause dismantling of existing turbines in repowering projects. Other aesthetic factors include the number of turbines in a location, the distance between farms and the array layout in relation to other existing wind farms. Guidelines exist to portray and evaluate the visual impact ${ }^{40}$; however, the final decision rests with the municipality.

(4) Aesthetics or noise. This category comprises those turbines that interviewees could not place into any individual of the two categories, but for which they were certain it was one of these two reasons. Note that for a turbine to be placed in this category, interviewees had to explicitly exclude politics as a possible reason for dismantling.

(5) Politics. Politics may have an impact on the dismantling of existing turbines during local development and planning dialogues, where informal requests by local politicians, proactive suggestions by developers or voluntary agreements by both parties come into play. In Denmark, wind project developers must obtain approval from the majority of local politicians in the municipality. Therefore, the developers engage with individual politicians during the planning process. During these negotiations, developers are sometimes met with informal requests to dismantling existing turbines located in the municipality. Developers see these informal requests as a requirement for achieving support for the project and the dismantling a necessary action to receive approval for the project.

(6) Politics or aesthetics. This category comprises those turbines that are dismantled either because of aesthetics or politics. Interviewees mentioned that local politicians tend to use the disturbance of aesthetic values in the landscape to argue for the removal of existing turbines. Using the visual impact illustrations from the EIA, local politicians would address their view on the disturbance in aesthetic values and argue for dismantling of existing turbines. As no firm regulation exists, but only guidelines for evaluating visual impact, it was often impossible for interviewees to select between aesthetic or political motivations behind dismantling requirements of a specific turbine.

(7) Politics, aesthetics or noise. For turbines in this category, interviewees excluded space as a reason for dismantling, but could not point to any other individual reason. Many of the interviewees noted that, during the early evaluation of the new development site, potentially problematic existing turbines are already identified on a more intuitive basis or from experience. Assuming the removal of those existing turbines before entering the permitting process can save time on wind farm design, noise calculations, and the visual impact assessment. This makes it difficult to (in retrospective) point toward a specific dismantling reason, as, e.g., the respective analyses for noise and aesthetics have never been undertaken. For turbines in this category, interviewees could not rule out politics as a reason, either. Here, some noted that it was common to proactively offer dismantling turbines that are known to be unwanted by politicians in the municipality to create a good start for negotiation during the permitting process.

(8) Unclassified. All dismantled turbines that the local development plans or the interviews did not cover are put into this category. 
Having identified and defined all categories for dismantling turbines in repowering projects, we analysed the interview transcripts and notes and added categories to all identified dismantled turbines in our database. Of the 221 dismantled repowering turbines, only two turbines remain without category.

\section{Value of lost production}

We approximate the value of lost production specifically for each turbine dismantled in repowering projects by multiplying its annual production averaged over its lifetime (obtained from the master data registry of wind turbines ${ }^{31}$ ) with the wind weighted electricity price ${ }^{41}$ for Denmark in each year from the dismantling of the wind turbine until the respective wind turbine would have reached a lifetime of 24.5 years (corresponding to the average lifetime of non-repowered dismantled turbines). We approximate operations and maintenance cost assuming 30-35 EUR/MWh ${ }^{35}$, an expectedly high level because of the turbine age (which is between 18.6 and 24.4 years during the lost years of production).

\section{Data Availability}

The dataset generated during the current study is published as Supplementary Data 1 (spreadsheet format). While the data set contains all quantitative data collected from the different sources, we cannot disclose specific disaggregate information from the interviews, which have been conducted under the Chatham House rules. Interview transcripts and notes may be requested from the authors but will only be handed out after explicit consent from the interviewees.

\section{Ethical Compliance}

We have complied with all relevant ethical regulations. The interviews were conducted in Denmark by the Technical University of Denmark according to the guidelines. All interactions followed Chatham House rules. We have obtained informed consent from all interview participants.

\section{Corresponding author}

Please direct all enquiries, including those for data and other materials, to the corresponding author Lena Kitzinglkit@dtu.dk.

\section{Acknowledgements}

This work constitutes a contribution to the research in the international working group IEA TCP Wind Task 26 (Cost of Wind Energy). We would like to thank all members of the group for their extraordinary collaboration and essential comments to our work that formed this article. The work has been in part funded by the Danish public Energy Technology Development and Demonstration Program (EUDP), project number 64018-0577. This article constitutes a contribution from the European Commission to IEA Task 26 research. The views expressed are purely those of the authors and may not in any circumstances be regarded as stating an official position of the European Commission. This work was authored [in part] by the National Renewable Energy Laboratory, operated by Alliance for Sustainable Energy, LLC, for the U.S. Department of Energy (DOE) under Contract No. DE-AC36-08GO28308. Funding provided by the U.S. Department of Energy Office of Energy Efficiency and Renewable Energy Wind Energy Technologies Office. 


\section{Author contributions}

LK and MKJ conceived the study, developed the analysis and undertook the interviews. MKJ led the data processing and analysis, with support by LK. EL and TT contributed with international data. All authors contributed to data analysis and interpretation. All authors wrote and edited the paper.

\section{Competing interests}

The authors declare no competing financial or non-financial interests.

\section{Additional information}

The views expressed in the article do not necessarily represent the views of the DOE or the U.S. Government. The U.S. Government retains and the publisher, by accepting the article for publication, acknowledges that the U.S. Government retains a nonexclusive, paid-up, irrevocable, worldwide license to publish or reproduce the published form of this work, or allow others to do so, for U.S. Government purposes.

\section{References}

1. Global Wind Council Energy GWEC. Global wind energy report 2018, 1-61. www.gwec.net/globalwind-report-2018 (2019).

2. WindEurope. Wind energy in Europe in 2018 - Trends and statistics. www.windeurope.org/wpcontent/uploads/files/about-wind/statistics/WindEurope-Annual-Statistics-2018.pdf (2019).

3. Energinet. Rekord lav CO2-udledning fra danskernes elforbrug i 2019. www.energinet.dk/Omnyheder/Nyheder/2020/01/16/Rekord-lav-CO2udledning-fra-danskernes-elforbrug-i-2019

(2020).

4. Lantz, E., Leventhal, M. \& Baring-Gould, I. Wind power project repowering: Financial feasibility, decision drivers, and supply chain effects. Prepared under Task No. WE11.0630, Technical Report NREL/TP6A20-60535. www.nrel.gov/docs/fy14osti/60535.pdf (2013).

5. Silvosa, A. C., Gómez, G. I. \& Del Río, P. Analyzing the techno-economic determinants for the repowering of Wind Farms. Eng. Econ. 58, 282-303 (2013).

6. Ziegler, L., Gonzalez, E., Rubert, T., Smolka, U. \& Melero, J. J. Lifetime extension of onshore wind turbines: A review covering Germany, Spain, Denmark, and the UK. Renew. Sustain. Energy Rev. 82, 1261-1271 (2018).

7. Scherhaufer, P., Höltinger, S., Salak, B., Schauppenlehner, T. \& Schmidt, J. Patterns of acceptance and non-acceptance within energy landscapes: A case study on wind energy expansion in Austria. Energy Policy 109, 863-870 (2017).

8. Smallwood, K. S. The Challenges of Addressing Wildlife Impacts When Repowering Wind Energy Projects. in Wind Energy and Wildlife Interactions (2017). doi:10.1007/978-3-319-51272-3_10.

9. Steininger, G. Wind Turbine Repowering Is on the Horizon (L. Buchsbaum and S. Patel, Interviewer). POWER Magazine (2016).

10. Villena-Ruiz, R., Ramirez, F. J., Honrubia-Escribano, A. \& Gómez-Lázaro, E. A techno-economic analysis of a real wind farm repowering experience: The Malpica case. Energy Convers. Manag. 172, 182-199 (2018). 
11. Filgueira, A., Seijo, M. A., Munoz, E., Castro, L. \& Piegari, L. Technical and economic study of two repowered wind farms in Bustelo and San Xoán, 24.7 MW and 15.84 MW respectively. in 2009 International Conference on Clean Electrical Power, ICCEP 2009 (2009). doi:10.1109/ICCEP.2009.5211998

12. Prabu, T. \& Kottayil, S. K. Repowering a wind farm - A techno-economic approach. Wind Eng. 39(4), 385-397 (2015). doi:10.1260/0309-524X.39.4.385

13. Nivedh, B., Devi, R. \& Sreevalsan, E. Repowering of wind farms - A case study. Wind Eng. 37(2), 137-150 (2013). doi:10.1260/0309-524X.37.2.137

14. Paul, A. \& Prabu, T. Technical and economic feasibility study on repowering of wind farms. Indian J. Sci. Technol. 9(38), 1-9 (2016). doi:10.17485/ijst/2016/v9i38/101960

15. Goyal, M. Repowering-Next big thing in India. Renew. Sustain. Energy Rev. 14, 1400-1409 (2010).

16. Del Río, P., Calvo Silvosa, A. \& Iglesias Gómez, G. Policies and design elements for the repowering of wind farms: A qualitative analysis of different options. Energy Policy 39, 1897-1908 (2011) doi:10.1016/j.enpol.2010.12.035.

17. Santos-Alamillos, F. J., Thomaidis, N. S., Usaola-García, J., Ruiz-Arias, J. A. \& Pozo-Vázquez, D. Exploring the mean-variance portfolio optimization approach for planning wind repowering actions in Spain. Renew. Energy 106, 335-342 (2017) doi:10.1016/j.renene.2017.01.041.

18. Möller, B. Changing wind-power landscapes: Regional assessment of visual impact on land use and population in Northern Jutland, Denmark. Appl. Energy 83, 477-494 (2006).

19. Himpler, S. \& Madlener, R. Optimal timing of wind farm repowering: A two-factor real options analysis. J. Energy Mark. 7(3), 3-34 (2014). doi:10.21314/JEM.2014.111.

20. WindEurope. Wind Energy in Europe: Outlook to 2023. www.windeurope.org/members-area/wpcontent/uploads/files/protected/market-intelligence/reports/Wind-Energy-Outlook-to-2023.pdf (2019).

21. Lacal-Arántegu, R., Iglesias, A. \& María Yusta, J. Technology effects in repowering wind turbines. Wind Energy 23(3), 660-675 (2019). doi:10.1002/we.2450.

22. Frantál, B. Have Local Government and Public Expectations of Wind Energy Project Benefits Been Met? Implications for Repowering Schemes. J. Environ. Policy Plan. 17, 217-236 (2015).

23. Martínez, E., Latorre-Biel, J. I., Jiménez, E., Sanz, F. \& Blanco, J. Life cycle assessment of a wind farm repowering process. Renew. Sustain. Energy Rev. 93, 260-271 (2018).

24. Manchado, C. et al. Wind farm repowering guided by visual impact criteria. Renew. Energy 135, 197207 (2019). doi:10.1016/j.renene.2018.12.007.

25. Hötker, H., Thomsen, K.-M. \& Jeromin, H. Impacts on biodiversity of exploitation of renewable energy sources: the example of birds and bats - facts, gaps in knowledge, demands for further research, and ornithological guidelines for the development of renewable energy exploitation. Report by Michael-Otto-Institut for the Nature and Biodiversity Conservation Union (NABU), Bergenhausen (2006).

26. Smallwood, K. S. \& Karas, B. Avian and Bat Fatality Rates at Old-Generation and Repowered Wind Turbines in California. J. Wildl. Manage. 73(7), 1062-1071 (2009). doi:10.2193/2008-464

27. Marques, A. T. et al. Understanding bird collisions at wind farms: An updated review on the causes and possible mitigation strategies. Biol. Conserv. 179, 40-52 (2014).

28. Ferri, V., Battisti, C. \& Soccini, C. Bats in a Mediterranean Mountainous Landscape: Does Wind Farm Repowering Induce Changes at Assemblage and Species Level? Environ. Manage. 57, 1240 1246 (2016).

29. Colmenar-Santos, A., Campíñez-Romero, S., Pérez-Molina, C. \& Mur-Pérez, F. Repowering: An 
actual possibility for wind energy in Spain in a new scenario without feed-in-tariffs. Renewable and Sustainable Energy Reviews 41, 319-337 (2015). doi:10.1016/j.rser.2014.08.041.

30. Danish Business Authority. Searchlist over all plan proposals and plans adopted pursuant to the Planning Act. www.kort.plandata.dk/searchlist/\#/ (2019).

31. Danish Energy Agency. Master Data Register for Wind turbines - Data on operating and decommissioned wind turbines (ultimo 02 2020) - Downloaded March 26, 2020. www.ens.dk/en/our-services/statistics-datakey-figures-and-energy-maps/overview-energy-sector (2020).

32. Danish Ministry of Taxation. Afgifts- og tilskudsanalysen på energiområdet-Delanalyse 6, Fremtidigt tilskud til landvind. www.skm.dk/media/1827232/Afgifts-og-tilskudsanalysen-delanalyse-6.pdf (2018).

33. Danish Ministry of Industry, Business and Financial Affairs. Bekendtgorelse om planlagning for og tilladelse til opstilling af vindmoller. www.retsinformation.dk/Forms/R0710.aspx?id=210040 (2019).

34. Danish Energy Agency. Vindmølleindustrien som historisk flagskib. Notat (report), 1-18. www.ens.dk/sites/ens.dk/files/Vindenergi/vindmoelleindustrien_historisk_flagskib.pdf (2011).

35. Strategic Energy Technologies Information System (SETIS). Wind Energy Generation. European Commission.

www.setis.ec.europa.eu/system/files/Technology_Information_Sheet_Wind_Energy_Generation. $\operatorname{pdf}(2013)$.

36. European Parliament and Council. Directive 2001/77/EC on the promotion of electricity produced from renewable energy sources in the internal energy market, OJ L 283/33 (2001).

37. Chatham House. Chatham House Rule. www.chathamhouse.org/chatham-house-rule (2020).

38. Danish Nature Agency under the Ministry of Environment and Food of Denmark. Vejledning om planlagning for og tilladelse til opstilling af vindmoller. ISBN 978-87-7279-173-9 (WEB) www.naturstyrelsen.dk/media/131731/vejledning_06012015_web.pdf (2015).

39. Environmental Protection Agency under the Ministry of Environment and Food of Denmark. Stoj fra vindmoller - Vejledning fra Mijostyrelsen $n r$. 1, ISBN 978-87-92903-08-2. www.mst.dk/Udgiv/publikationer/2012/05/978-87-92903-08-2.pdf (2012).

40. Danish Nature Agency under the Ministry of Environment and Food of Denmark. Vejledning om VVM $\quad i \quad$ planloven. $\quad$ ISBN 978-87-7091-029-3. www.naturstyrelsen.dk/media/nst/9948968/vvm_vejledning2.pdf (2009).

41. Ea Energianalyse. Integration of wind power. Report elaborated for Danish TSO Energinet. www.eaenergianalyse.dk/wp-

content/uploads/2020/02/1550_Integration_vindkraft_viking_link_og_andre_tiltag-2.pdf (2015).

42. Uihlein, A., Telsnig, T. \& Vazquez Hernandez, C. JRC Wind Energy Database, Joint Research Centre of the European Commission, Petten. (2019).

43. Lacal-Arántegui, R., Uihlein, A. Repowering wind turbines - Analysis of the effects of technology substitution in repowered wind farms. Appl. Energy 23, 660-675 (2020). 


\section{Supplementary Material}

to

\section{Multifaceted drivers for onshore wind energy repowering and their implications for energy transition}

Lena Kitzing*, Morten Kofoed Jensen*, Thomas Telsnig**, Eric Lantz***

* Energy Economics and Regulation Group,

Department of Technology, Management and Economics,

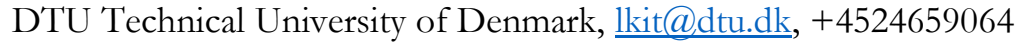

** European Commission, Joint Research Centre, Petten, The Netherlands

***National Renewable Energy Laboratory, Golden, Colorado, USA 


\section{Supplementary Note 1}

Denmark has a long history deploying wind power. Funded by the Danish government, physicist Poul La Cour invented the first wind turbine in 1891. Nevertheless, it was first in the 1970s, because of the oil crisis, that the technological development started to evolve ${ }^{1}$. Since then, wind energy has become a significant part of the energy system, comprising 41\% of Denmark's electricity demand in 20182. In August 2019, Denmark's wind fleet consisted of 4202 onshore (land-based) turbines (with a capacity larger than $25 \mathrm{~kW}$ ), comprising $4.4 \mathrm{GW}$, and 558 offshore turbines, comprising a total capacity of $1.7 \mathrm{GW}$. On average, the capacity size of onshore turbines is $1 \mathrm{MW}$, whereas the capacity for offshore turbines is $3 \mathrm{MW}^{3}$.

Repowering of wind energy facilities first emerged in California and Denmark in the early 1990s, followed by the Dutch and German markets in the 1990 s to $2000 s^{4}$. Denmark was the first country to politically support repowering with financial incentives, recognising that several small, aging turbines were an obstacle to new project development ${ }^{5}$. The first incentive program was available from 1994 to 1996. In this period, the government of Denmark created a fund of 10 million Danish Kroners (nominal) each year that developers could draw from to buy inappropriately located turbines, thereby hindering the installation of new turbines. However, only around one-third of the funds were used each year; hence, the success was questionable 6 .

The second incentive program, in place from 2001 to 2003, issued repowering certificates for dismantled turbines up to $150 \mathrm{~kW}$. The redemption of these certificates gave developers of new projects access to a higher feed-in tariff $(17 \varnothing \mathrm{re} / \mathrm{kwh}$ ) for up to 3 times the dismantled capacity (if the removed turbine was under $100 \mathrm{~kW}$ ) or up to twice the dismantled capacity (if the removed turbine was between $100 \mathrm{~kW}$ and $150 \mathrm{~kW}$ ). During this incentive program, 272 new turbines with a total capacity of 324 MW replaced 1480 existing turbines with a total capacity of $122 \mathrm{MW}^{6}$. The third repowering scheme targeted existing turbines with a capacity of $450 \mathrm{~kW}$ or less, again issuing repowering certificates and thereby giving related new turbines access to a higher fixed feed-in tariff of $12 \varnothing \mathrm{re} / \mathrm{kWh}$ with a ceiling price of $26 \varnothing \mathrm{re} / \mathrm{kWh}$ for up to twice the removed capacity.

Starting in 2005, the third repowering scheme aimed to replace $175 \mathrm{MW}$ of existing wind capacity with 350 MW of new capacity over a period of 5 years. However, because of a turnout less than expected, the Danish government agreed to extend the incentive program with 1 year from the end of 2009 and later once again extending it to the end of 2011. Moreover, the Danish government introduced an additional incentive option in 2008, rewarding developers with 8 øre $/ \mathrm{kWh}$ without the ceiling price. By the end of 2011, 146 new turbines (in total $348 \mathrm{MW}$ ), had been commissioned and 811 existing turbines, comprising $148 \mathrm{MW}$, had been dismantled as part of the third repowering scheme ${ }^{6}$.

These early repowering schemes in Denmark, as well as similar ones in Germany, provided financial incentives for developers to engage in repowering projects. However, they have been criticised for having led to a premature dismantling of turbines 7 . Today, there are no dedicated support mechanisms in place targeting repowering in Denmark. Nevertheless, repowering becomes an ever more significant part of onshore wind project development. This may be related to a changing political attitude toward wind power.

In the period from 2015 to 2016, there was a slowdown in onshore wind deployment in Denmark because of a combination of low electricity price forecasts and municipal opposition ${ }^{8}$. Several municipalities completely halted construction of new turbines, arguably due to local opposition or health concerns, whereas other municipalities paused, cancelled or stayed silent on permitting future onshore wind development during the period ${ }^{8}$. Further, local wind energy opposition groups started to gain the attention of politicians and media ${ }^{8}$. During this period, the aesthetics quality of wind power began to have a negative impact on the valuation of wind power for decision makers ${ }^{8}$. In 2018, this has culminated in a political agreement by national policymakers that the total number of onshore turbines in the country should not exceed 1850 turbines in 2030, which is a notable reduction from the roughly 4300 existing turbines in 2019 . 


\section{Supplementary Note 2}

Attaining a full understanding of the economic feasibility behind a repowering decision falls outside the scope of this study. Nevertheless, we find it informative to explore how repowering activity can improve the business case of an existing facility. We do this for a representative repowering project with five commissioned turbines and six dismantled turbines based on the median repowering project information, which is a fictive project representative of our sample (see Supplementary Figure 1). The project comprises of five commissioned turbines of 3.3 MW each (in total 16.5MW) and six dismantled turbines of $600 \mathrm{~kW}$ (in total $3.6 \mathrm{MW}$ ), hence a net repowering factor of 4.58 .

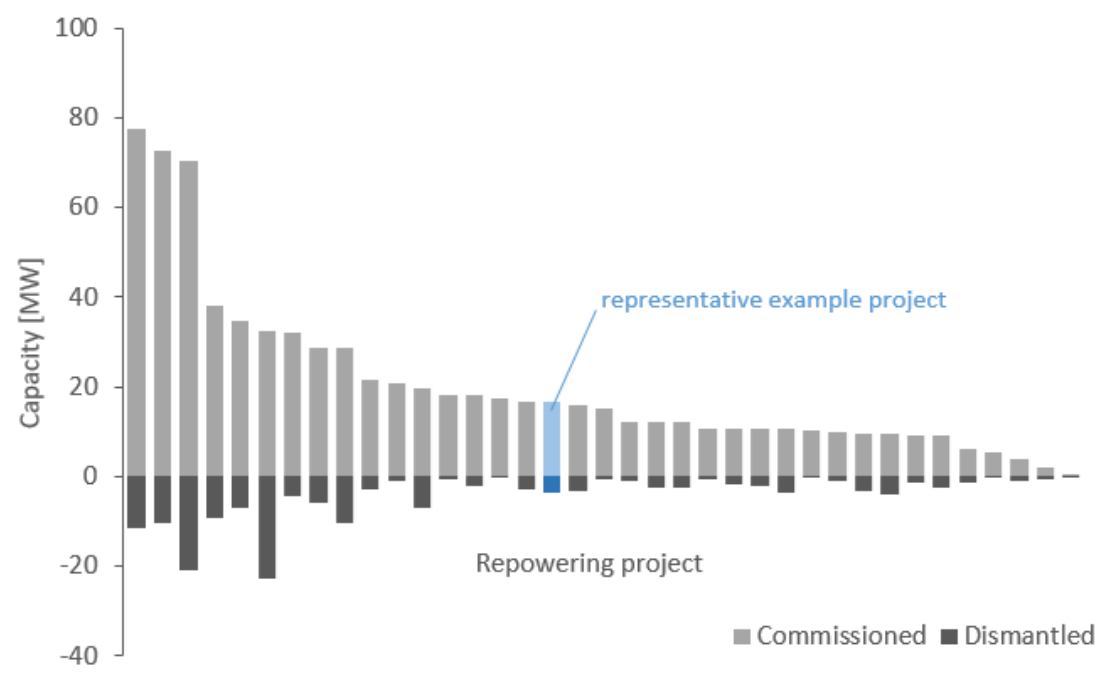

Supplementary Figure 1 All repowering projects in Denmark between 2012 and 2019, ordered by commissioned capacity, and the representative example project used in the illustrative business case calculation. The blue marked project is an imagined representation of a typical repowering project, used in the sample business case calculation.

Supplementary Table 1 depicts the project-level details of the representative repowering project, comparing the dismantled turbines against the commissioned ones. It becomes apparent that there is a significant difference in size between the old and new technology, resulting in almost six times higher capacity and a nine percentage points increase in capacity factor. This leads to an approximately six-fold increase in annual net cash flows (revenues minus operational and maintenance cost). This considerable increase in annual net cash flows can justify the new investment under medium to high market price scenarios were the potential annual profit from repowering is positive. It is important to bear in mind that our calculations are highly simplified and do not include subsidies on the dismantled nor the commissioned turbines, which could significantly affect the calculation. 


\begin{tabular}{|c|c|c|}
\hline & \multicolumn{2}{|c|}{ 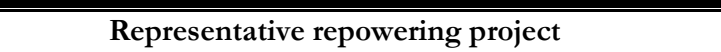 } \\
\hline & Dismantled & Commissioned \\
\hline Number of turbines & 6 & 5 \\
\hline Commissioning year & 1997 & 2016 \\
\hline Capacity per turbine & $600 \mathrm{~kW}$ & $3300 \mathrm{~kW}$ \\
\hline Hub height & $45 \mathrm{~m}$ & $94 \mathrm{~m}$ \\
\hline Rotor diameter & $44 \mathrm{~m}$ & $112 \mathrm{~m}$ \\
\hline Full load hours (capacity factor) & $1930 \mathrm{~h}(22 \%)^{*}$ & $2727 \mathrm{~h}(31 \%)^{*}$ \\
\hline Investment cost & $1.242 € / \mathrm{kW}^{10}$ & $1.174 € / \mathrm{kW}^{11}$ \\
\hline Purchase of existing turbines & & $0-0.5$ mio $€$ per turbine** \\
\hline Operations and Maintenance cost & $1,55 \mathrm{c} € / \mathrm{kWh}^{10}$ & $1,25 \mathrm{c} € / \mathrm{kWh}^{11}$ \\
\hline Cost of capital (real) & $3.2^{12}$ & $3.2^{2} 0^{12}$ \\
\hline Levelised Cost of Electricity LCOE & $53,4 € / \mathrm{MWh}$ & $37,9-41,9 € / \mathrm{MWh}$ \\
\hline $\begin{array}{l}\text { Annual Net Cash Flows (at assumed electricity price } \\
\text { between } 35-55 \text { EUR/MWh) }\end{array}$ & $0.2-0.4$ mio $€^{* * *}$ & $1.5-2.4$ mio $€^{* * *}$ \\
\hline Annuity of investment cost & Assumed amortised & $1.3-1.5 \mathrm{mio} €$ \\
\hline Potential annual profit from repowering & $-0.4 n$ & $.9 \operatorname{mio} €$ \\
\hline
\end{tabular}

Numbers not cited or marked are based on our database or own calculations. Prices are given in real 2019 values * Based on a yearly average over the production time. ${ }^{* *}$ Data derived from interviews and from ref. ${ }^{10}$. ${ }^{* *}$ Subsidies/Support not included. The potential annual profit from repowering is calculated for the lower end of the range from the lowest annual net cash flows of the commissioned project deducting the highest 'lost' cash flows of the dismantled turbines and the highest annuity of investment; and for the higher end of the range from the highest annual net cash flows of the commissioned project deducting the lowest 'lost' cash flows of the dismantled turbines and the lowest annuity of investment cost.

\section{Supplementary Note 3}

Annual variation in overall wind energy project development: The annual total capacity installed and dismantled depict considerable changes over the years, ranging from 98 MW in 2014 to 298 MW in 2017. One of our interviewees explained these two extrema to be caused by changes in the subsidy scheme, which incentivized the industry to complete wind projects in the years preceding the respective subsidy scheme changes, accelerating forward investment decisions that might otherwise only have been relevant in later years. This occurred first when in 2014 the Danish government introduced a ceiling on the received premium in the feed-in-premium system, along with a new way of calculating the duration of the support (depending on a combination of full load hour production and swept area) ${ }^{13}$. As a result, the installed capacity dropped by 66\% in 2014 compared to the previous year. It occurred again in February 2018, as the Danish government changed the support scheme from an administratively set premium to a tendering process, leading to a significant decrease in annual total installed capacity in 2018 compared to 2017.

The timing of projects is also not always fully plannable for developers. One interviewee mentioned that in a specific case, the permission of their proposal for a repowering project was granted much faster than expected, due to no complaints in the local area. As a result, the dismantling of the existing turbines occurred 1.5 years earlier than expected. 
Project sizes: Repowering projects are $46.6 \%$ larger on average (gross capacity addition) compared to greenfield projects, as depicted in Supplementary Figure 2. The average size of new turbines installed in repowering projects is $3.3 \mathrm{MW}$, noticeably larger than those used in greenfield projects (3.0 MW). There are also higher outlier values in repowering projects, such as three repowering projects each with a capacity of more than $70 \mathrm{MW}$. The largest repowering project, measured by capacity, had 18 new turbines installed with a total of 77.4 MW, in contrast, the largest greenfield project consisted of 13 turbines, comprising 46.8 MW.

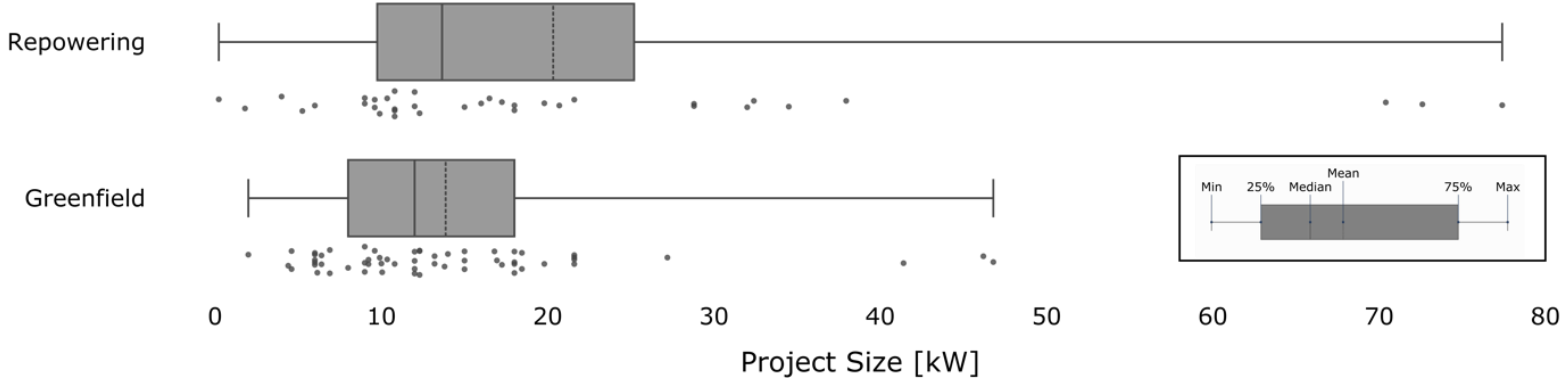

Supplementary Figure 2 Project sizes in Danish greenfield and repowering projects. The figure depicts a boxplot comparing the project sizes in regard to installed capacity between repowering and greenfield projects in the period 2012-2019.

Project developers: In total, 21 companies, associations or private investors have developed repowering projects in Denmark between 2012-2019. The most prolific company developed six projects, followed by two companies with four and five projects, respectively. Seventeen companies, associations and private investors only had a single repowering project in the period, with on average 3.75 turbines (with the exception of two larger 22 turbine projects), see Supplementary Figure 3.

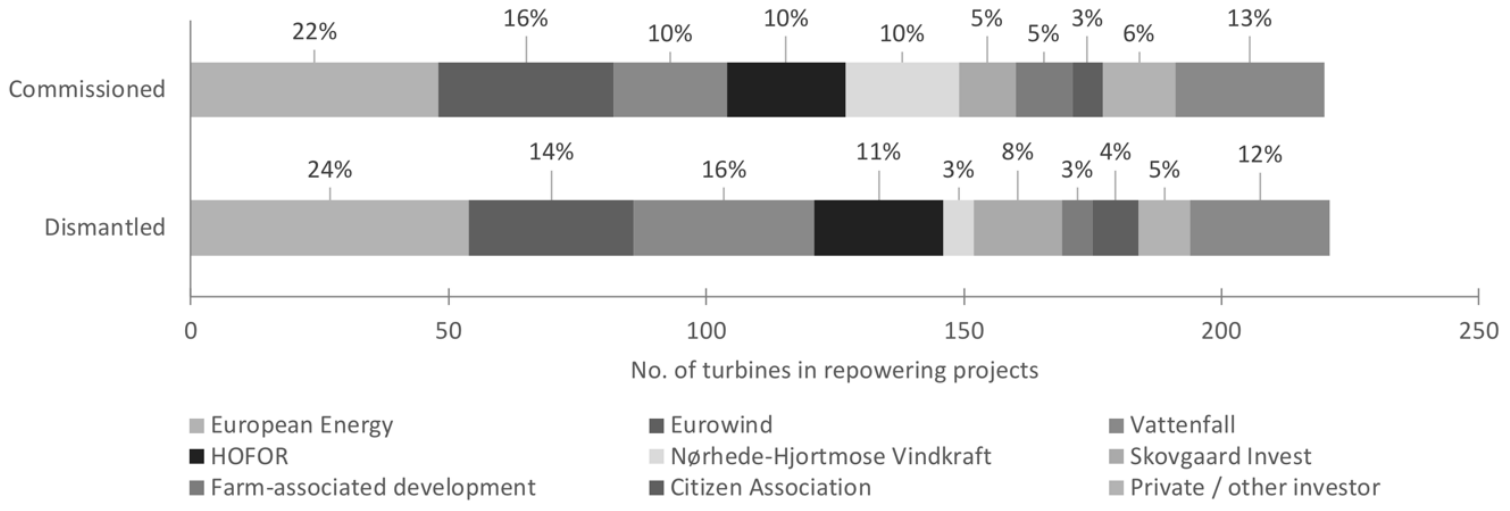

Supplementary Figure 3 Market shares of project developers in Danish repowering projects. The figure depicts market shares in regard to number of turbines, across all repowering projects developed in the period 2012-2019. See Supplementary File 1 for project-level details.

Turbine manufacturers: The Danish wind turbine manufacturing industry has gone through a period of much consolidation. The 18 different manufacturers initially registered for turbines in Denmark have now consolidated into two main manufacturers (Siemens and Vestas). Together, they make $100 \%$ of the greenfield market and at least $85 \%$ of the repowering market for newly installed turbines, see Supplementary Figure 4. 


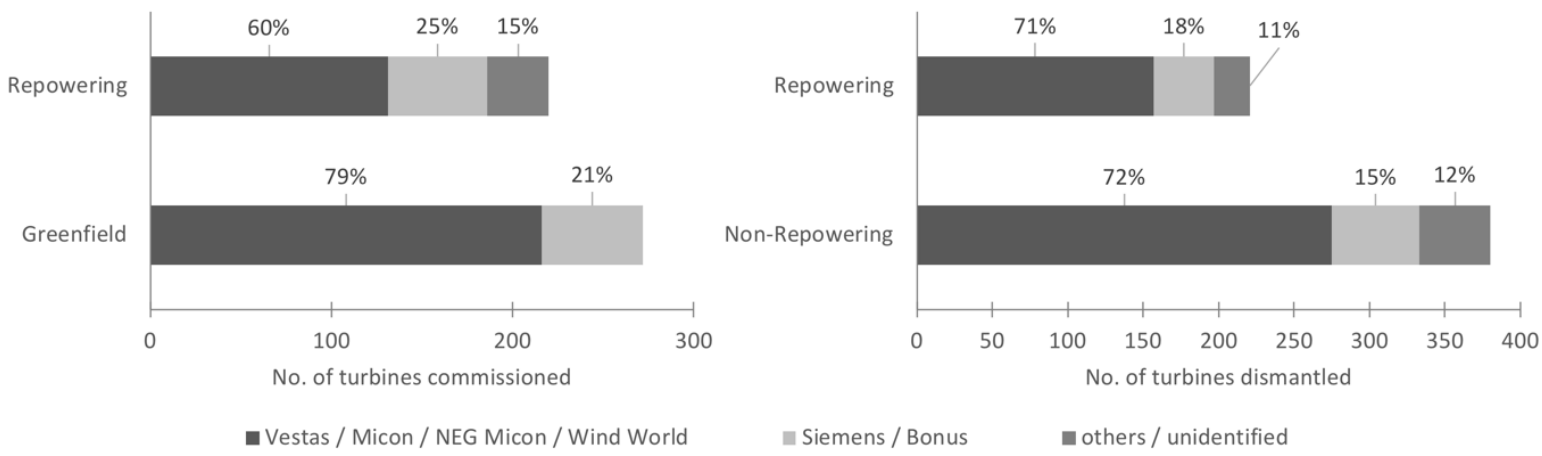

Supplementary Figure 4 Market shares of turbine manufacturers in Danish wind projects. The figure depicts market shares in regard to number of turbines, across all greenfield and repowering projects, as well as non-repowered dismantling developed in the period 2012-2019. See Supplementary Data 1 for turbine-level details.

\section{Supplementary References}

1. Vestergaard, J., Brandstrup, L. \& Goddard, R. D. A Brief History of the Wind Turbine Industries in Denmark and the United States. Academy of International Business (Southeast USA Chapter), Conference Proceedings, 322-327 (2004).

2. WindEurope. Wind energy in Europe in 2018 - Trends and statistics. www.windeurope.org/wpcontent/uploads/files/about-wind/statistics/WindEurope-Annual-Statistics-2018.pdf (2019).

3. Danish Energy Agency. Master Data Register for Wind turbines - Data on operating and decommissioned wind turbines (ultimo 02 2020) - Downloaded March 26, 2020. www.ens.dk/en/ourservices/statistics-data-key-figures-and-energy-maps/overview-energy-sector (2020).

4. Lantz, E., Leventhal, M. \& Baring-Gould, I. Wind power project repowering: Financial feasibility, decision drivers, and supply chain effects. Prepared under Task No. WE11.0630, Technical Report NREL/TP6A20-60535. www.nrel.gov/docs/fy14osti/60535.pdf (2013).

5. Goyal, M. Repowering-Next big thing in India. Renew. Sustain. Energy Rev. 14, 1400-1409 (2010).

6. WindDenmark. DKWIND Faktablad 11: Udskiftning af vindmoller (Factsheet 11: Repowering of Wind Turbines), avaliable on request from WindDenmark: www.winddenmark.dk/kontakt (2017).

7. Steininger, G. Wind Turbine Repowering Is on the Horizon (L. Buchsbaum and S. Patel, Interviewer). POWER Magazine (2016).

8. Mortensen, H. B. The V aluation History of Danish Wind Power: The Ongoing Struggle of a Challenger Technology to Prove its Worth to Society. PhD thesis, Aalborg University, Denmark (2018) doi:10.5278/vbn.phd.tech.00040

9. Danish Government and Danish Parliament. Energiaftale af 29. juni 2018 (Energy Agreement). www.regeringen.dk/publikationer-og-aftaletekster/energiaftale (2018).

10. Nielsen, P. et al. Vindmollers okonomi. UEDP project 33033-0196, EMD International A/S www.emd.dk/files/Vindmøllers økonomi_EMD-Feb2010.pdf (2010) . 
11. IEA Wind TCP Task 26. Data Viewer. International Energy Agency. www.community.ieawind.org/task26/dataviewer (2020).

12. Dukan, M., et al. Effect of auctions on financing conditions for renewable energy. Report D5.1, AURESII project under the European Union's Horizon 2020 Framework Programme for research and innovation, grant no. 817619 (2019).

13. Danish Energy Agency. Oversigt over stotteregler mv. for elproduktion baseret på vedvarende energi og anden miljovenlig elproduktion. Notat (report). www.ens.dk/sites/ens.dk/files/contents/service/file/ oversigt_over_stoette_til_ve_m.dato_.pdf (2018). 